\title{
Eastern comma, hop merchant, comma angelwing, Polygonia comma (Harris) (Insecta: Lepidoptera: Nymphalidae: Nymphalinae) ${ }^{1}$
}

Donald W. Hall and Jerry F. Butler ${ }^{2}$

\section{Introduction}

Species in the genus Polygonia are referred to collectively as the anglewings. The eastern comma, Polygonia comma (Harris), is also known as the hop merchant and the comma anglewing (Miller 1992). It is a relative small inconspicuous butterfly that is rather closely associated with moist woods where its preferred nettle hosts grow, but it sometimes strays into other areas. With its wings folded, it resembles a dead leaf and is highly cryptic.

\section{Distribution}

The eastern comma is found throughout most of the eastern U.S. south to north central Florida and the northern Gulf states, and west to eastern Wyoming and Colorado (Opler et al. 2009).

\section{Description}

Adults: The wing spread of adults is 1.75 to 2.0 inches (Allen 1997). The eastern comma can be differentiated from the closely related questionmark (Polygonia interrogationis [Fabricius]) by the silvery comma in the middle of the hind wing (lacking the dot of the questionmark), its smaller size, less strongly hooked forewing margin, and shorter hind wing tail. As with the questionmark, there are two color forms that generally correlate with the "summer" and "winter" adult generations. The upper side of the hind wings is predominantly black in the summer form and mostly orange in the winter generation.

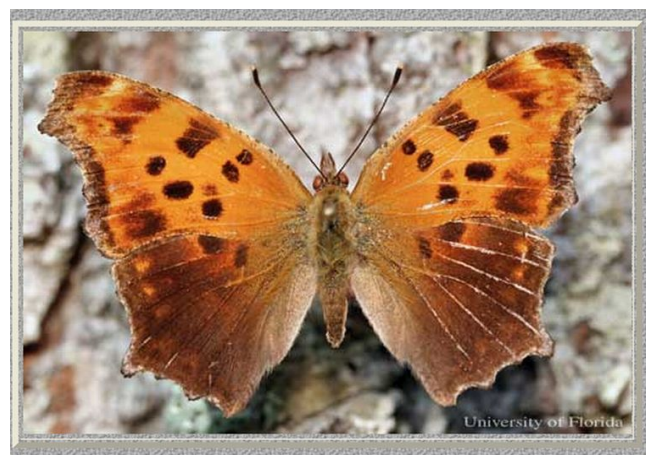

Figure 1. A dorsal view of summer form of an adult eastern comma, Polygonia comma (Harris). (Perry County, Indiana.)

1. This document is EENY-455, one of a series of Featured Creatures from the Entomology and Nematology Department, Florida Cooperative Extension Service, Institute of Food and Agricultural Sciences, University of Florida. Published: June 2009. This document is also available on Featured Creatures Web site at http://creatures.ifas.ufl.edu. Please visit the EDIS Web site at http://edis.ifas.ufl.edu. Additional information on these organisms, including many color photographs, is available at the Entomology and Nematology Department website at http://entnemdept.ifas.ufl.edu/

2. Donald W. Hall, professor; Jerry F. Butler, professor; Department of Entomology and Nematology; Florida Cooperative Extension Service, Institute of Food and Agricultural Sciences, University of Florida, Gainesville, FL 32611.

The Institute of Food and Agricultural Sciences (IFAS) is an Equal Opportunity Institution authorized to provide research, educational information and other services only to individuals and institutions that function with non-discrimination with respect to race, creed, color, religion, age, disability, sex, sexual orientation, marital status, national origin, political opinions or affiliations. U.S. Department of Agriculture, Cooperative Extension Service, University of Florida, IFAS, Florida A. \& M. University Cooperative Extension Program, and Boards of County Commissioners Cooperating. Millie Ferrer, Interim Dean 


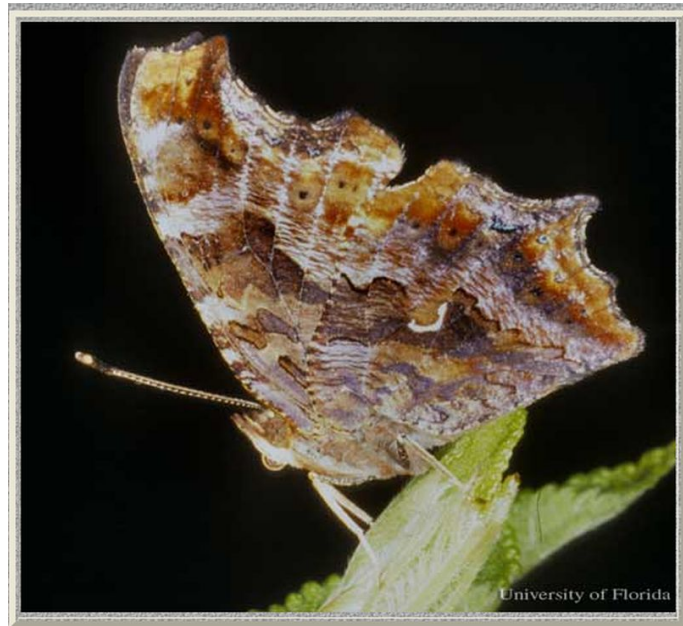

Figure 2. A ventral view of an adult eastern comma, Polygonia comma (Harris). (Perry County, Indiana.)

Eggs: Eggs are green and the surface is sculptured with a series of vertical ridges

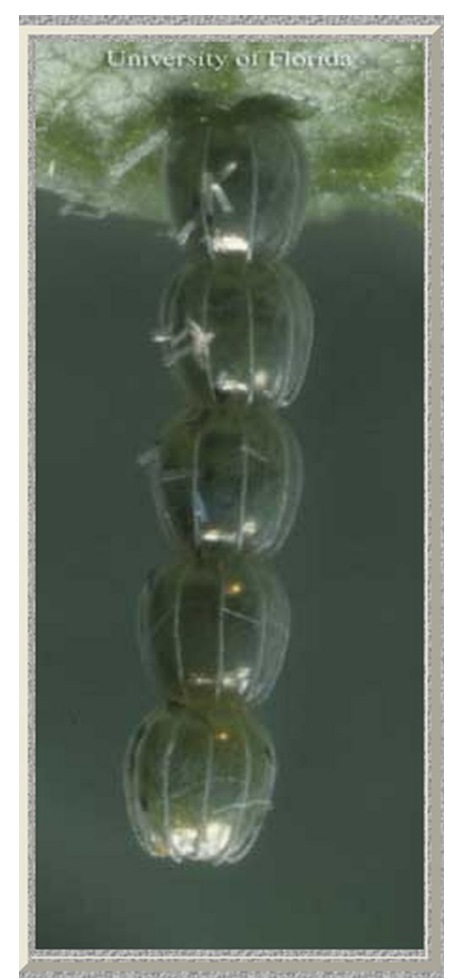

Figure 3. Eggs of the eastern comma, Polygonia comma (Harris).

Larvae: Full grown larvae are approximately 1.2 inches in length (Minno et al. 2005). The head has short spines and a pair of branching spines on top. Body color is highly variable, from white to greenish-brown to black, and the branching spines (scoli) on the body are also variable from black to white with black tips (Opler and Krizek 1984, Scott 1984).

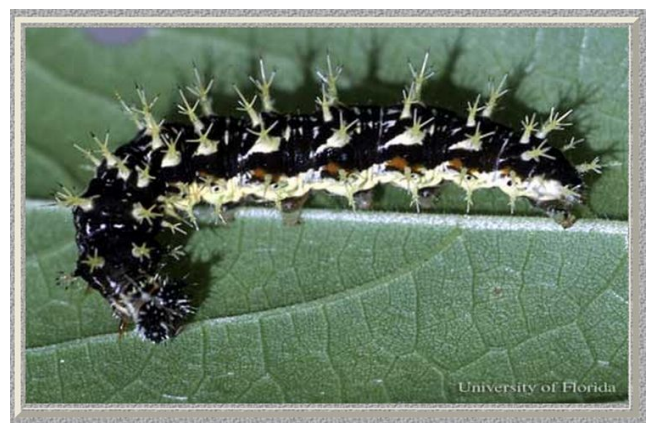

Figure 4. Larva of the eastern comma, Polygonia comma (Harris). (Perry County, Indiana.)

Pupae: Pupae are variable in color but always have prominent ventral gold or silver spots. The pupae are attached to a silk pad by the cremaster.

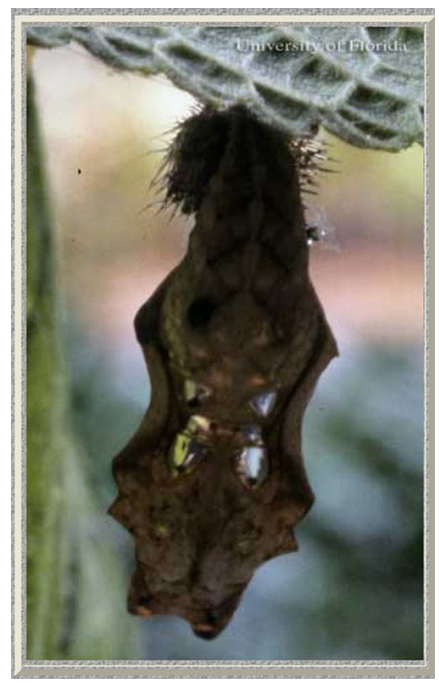

Figure 5. Ventral view of the pupa of the eastern comma, Polygonia comma (Harris), showing silvery patches . (Perry County, Indiana.)

\section{Life Cycle and Biology}

There are two generations per year, with the summer brood probably estivating for much of the summer as adults and the fall-winter brood overwintering as adults (Opler et al. 2009). Adults feed on fermenting fruit and tree sap but rarely on flower nectar (Scott 1986). Males perch in the sun on foliage or tree trunks to await females (Opler and Krizek 1984) and defend territories (Bitzer and Shaw 1983).

Eggs are laid singly or in stacks on the undersides of leaves or less commonly on twigs. Larvae rest on the undersides of leaves and make nests by silking together the two sides. They hide in the nests during the daytime and feed at night. 


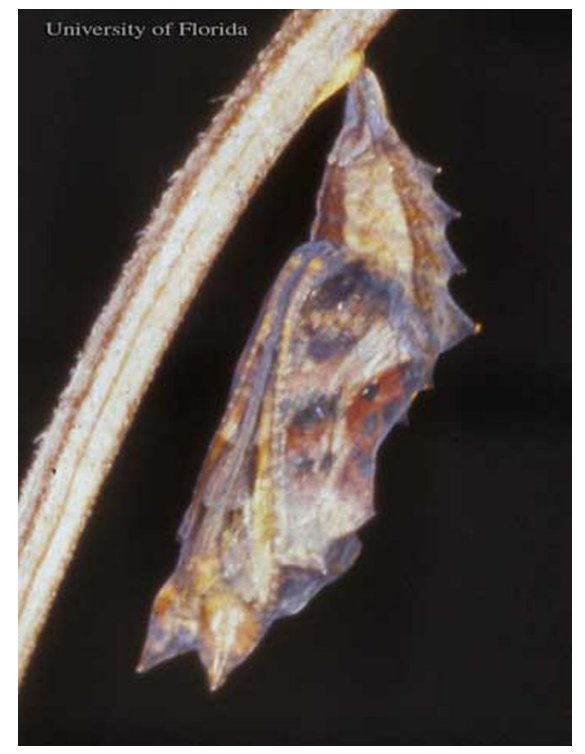

Figure 6. Pupa of the eastern comma, Polygonia comma (Harris), just prior to emergence of adult. (Perry County, Indiana.)

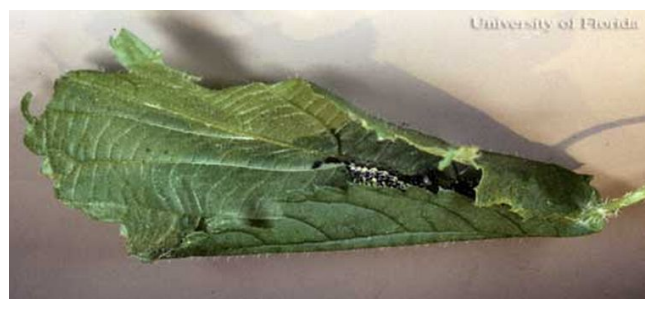

Figure 7. Leaf nest of the eastern comma, Polygonia comma (Harris), with larva inside.

\section{Hosts}

The larval hosts of the eastern comma are:

- Urticaceae - nettles

- Canadian woodnettle, Laportea canadensis [L.] Weddell

- Urtica species

- false nettle, Boehmeria cylindrica [L.] Sw.

Ulmidae - elms

- American elm, Ulmus Americana L.

Cannabaceae - hemps

- common hop, Humulus lupulus L.

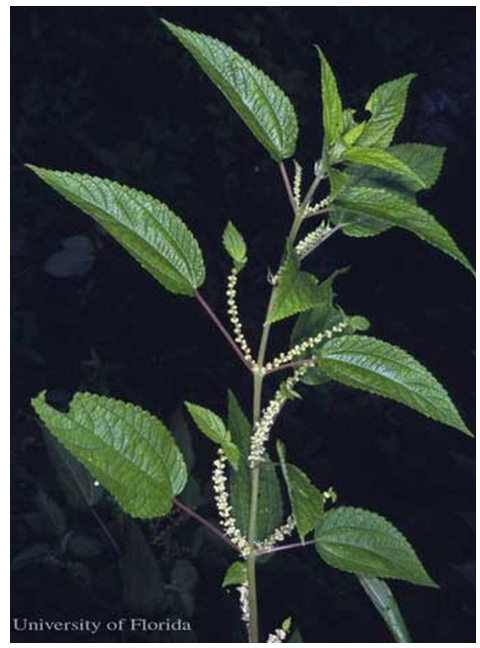

Figure 9. False nettle, Boehmeria cylindrica (L.) Sw., a host of the eastern comma, Polygonia comma (Harris).

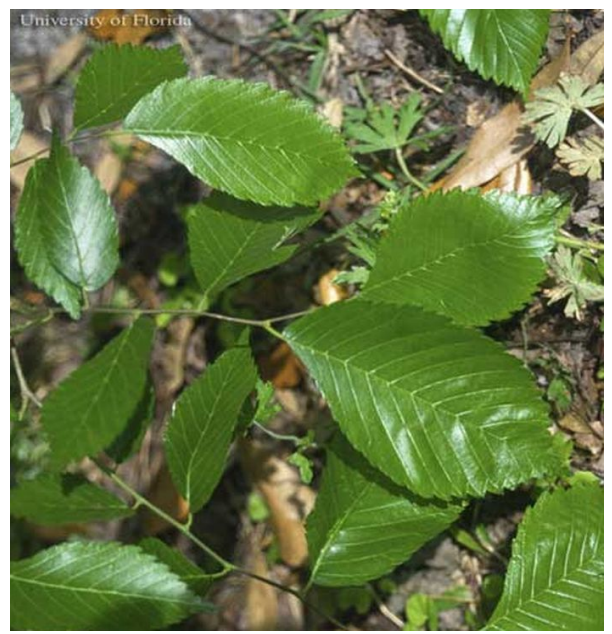

Figure 10. American elm, Ulmus americana L., a host of the eastern comma, Polygonia comma (Harris).

\section{Economic Importance}

Eastern comma larvae are occasionally found on common hops, Humulus lupulus L. The name hop merchant was originally assigned to the pupa (and later transferred to the adult butterfly) and is based on the practice of farmers predicting the future price of hops based on the variation in the silver and gold spots on the pupae (Weed 1917). The eastern comma does little damage to commercially grown hops and is of no economic importance (Hawley 1918). In fact, virtually all current commercial hops agriculture in the United States is in the Pacific Northwest and outside the distribution of the eastern comma. 


\section{Selected References}

Allen TJ. 1997. The Butterflies of West Virginia and their Caterpillars. University of Pittsburgh Press. Pittsburgh, Pennsylvania. 400 pp.

Bitzer RJ, Shaw KC. 1983. Territorial behavior of Nymphalis antiopa and Polygonia comma (Nymphalidae). Journal of the Lepidopterists' Society 37: 1-13.

Cech R, Tudor G. 2005. Butterflies of the East Coast: An Observer's Guide. Princeton University Press. Princeton, New Jersey. 345 pp.

Glassberg J, Minno C, Calhoun JV. 2000. Butterflies through Binoculars: Florida. Oxford University Press. New York, New York. 256 pp.

Hawley IM. 1918. Insects Injurious to the Hop in New York, with Special Reference to the Hop Grub and the Hop Redbug. Cornell University Agricultural Experiment Station. November 15. pp. 147-224.

Miller JY (editor). 1992. The Common Names of North American Butterflies. Smithsonian Institution Press. Washington, D.C. 177 pp.

Minno MC, Butler JF, Hall DW. 2005. Florida Butterfly Caterpillars and their Host Plants. University Press of Florida. Gainesville, Florida. 341 pp.

Opler, PA, Lotts K, Naberhaus T. (2009). Butterflies and Moths of North America. http://www.butterfliesandmoths.org/ (26 May 2009).

Opler PA, Krizek GO. 1984. Butterflies East of the Great Plains. The Johns Hopkins University Press. Baltimore, Maryland. 294 pp.

Scott JA. 1986. The Butterflies of North America: A Natural History and Field Guide. Stanford University Press. Stanford, California. 583 pp.

Weed CM. 1917. Butterflies Worth Knowing. Doubleday, Page and Company. Garden City, New York. 286 pp. 